\title{
Reducing Total Dissolved Solid of Livestock Wastewater with Moringa Seed Powder
}

\author{
I Made Merdana ${ }^{1 *}$, I Ketut Suada ${ }^{2}$, I Putu Agus Santika Putra ${ }^{3}$ \\ ${ }^{1}$ Laboratory of Veterinary Pharmacy and Pharmacology, Faculty of Veterinary Medicine, Udayana University \\ ${ }^{2}$ Laboratory of Veterinary Public Health, Faculty of Veterinary Medicine, Udayana University \\ ${ }^{3}$ Student of Veterinary Internship Program, Faculty of Veterinary Medicine, Udayana University \\ Jl. P.B. Sudirman, Denpasar, Bali, Indonesia \\ *Corresponding author: imade_merdana@unud.ac.id
}

\begin{abstract}
In recent years environmental pollution has become a problem that needs attention because it causes negative impacts on ecosystems. The increase in cattle raising is directly proportional to livestock waste produced both from feces and excreted urine. Most people do not know how to process animal wastewater, so they dispose the livestock waste into water areas such as rivers that flow close to settlements. Water quality can be measured by several parameters, one of which is total dissolved solids (TDS). This parameter states the amount of solute both organic and inorganic in a solution. Moringa seeds have a coagulant effect due to their cationic electronic poly protein content. The purpose of this study was to determine the effect of moringa seeds on reducing TDS of livestock wastewater. The sample of this study was cattle farm wastewater taken from the cages of members of the Walung Mekar farmer group. Moringa seed powder concentrations used in this study were $50 \mathrm{mg} / \mathrm{L}, 100 \mathrm{mg} / \mathrm{L}$ and $150 \mathrm{mg} / \mathrm{L}$. Observation was conducted in various time periods 0 minutes, 20 minutes, 40 minutes, 60 minutes. The TDS calculation method used gravimetric calculations (SNI 06-6989.27-2005). The results of variance indicated that Moringa oleifera powder had a very significant effect on the reduction of TDS levels in livestock wastewater. In summary, the best concentration of Moringa oleifera powder at $150 \mathrm{mg} / \mathrm{L}$ and the best deposition time at 60 minutes was able to reduce TDS levels.
\end{abstract}

Keywords: moringa seeds; livestock; wastewater; total dissolved solid

\section{INTRODUCTION}

A good and healthy environment as a niche for living and developing an organism, including humans is very necessary for life. The environment is a good and healthy environment if the organisms in it are able to live and develop normally by the conditions and supporting resources [1]. Water quality can be measured by several parameters, one of which is Total Dissolved Solid (TDS). This parameter states the amount of solute both organic and inorganic in a solution. This parameter is used to determine whether a water source is suitable to be used as a source of drinking water [2]. Based on the regulation of the Indonesia minister of environment, the maximum level of TDS for clean water quality is $2.000 \mathrm{mg} / \mathrm{L} \mathrm{[3]}$.

Moringa oleifera seeds contain 4- $(\alpha-\mathrm{L}-$ rhamnpyranosyloxy) benzyl isothiocyanate which has been identified as having antimicrobial activity. This component is a bacteriostatic compound which means it can inhibit bacterial growth or metabolic activity [4]. In addition to antimicrobial effects, Moringa seeds also have a coagulant effect due to their protein content which is cationic polyelectrolytes [5]. This means that the protein in
Moringa seeds can be used to purify water, the protein contains amino acids, and if dissolved in water will undergo ionization or dissociation [6].

\section{RESEARCH METHOD}

\section{Object of research}

The sample used was cattle livestock wastewater taken from the cages of members of the Walung Mekar farmer group, Mr. Subaga, in Serongga Village. It has the wastewater was usually dumped directly into the river without any prior processing.

\section{Research procedure}

Moringa seeds that are ripe or old are peeled from their shells and the seeds are taken and then dried in an oven at $105^{\circ} \mathrm{C}$ for 30 minutes to reduce the water content. Moringa seeds that have been dried, then crushed and sieved with a 60 mesh siever in order to get the fine Moringa seed powder. As much as 1 gram of Moringa seed powder was then dissolved with $200 \mathrm{ml}$ of distilled water so that a concentration of $5000 \mathrm{mg} / \mathrm{L}$ was obtained.

Moringa seed powder concentrations used in this study were $50 \mathrm{mg} / \mathrm{L}, 100 \mathrm{mg} / \mathrm{L}$ and $150 \mathrm{mg} / \mathrm{L}$. This 
determination of concentration is a modification of the study of Wibawarto [7]. Moringa seeds effectively improve the quality of domestic waste at a concentration of $40 \mathrm{mg} / \mathrm{L}$. The concentration used in this study was higher due to the characteristics of cattle farm waste such as turbidity, odor, acidity as well as organic and inorganic content different when compared to domestic waste.

Wastewater is prepared in each beaker glass of $500 \mathrm{ml}$, followed by coagulation process with Moringa seeds with a concentration of $\mathrm{P} 0=0 \mathrm{mg} / \mathrm{L}$ (control), $\mathrm{P} 1=50 \mathrm{mg} / \mathrm{L}$, $\mathrm{P} 2=100 \mathrm{mg} / \mathrm{L}, \mathrm{P} 3=150 \mathrm{mg} / \mathrm{L}$. Each sample was stirred quickly for 2 minutes at a stirring speed of $200 \mathrm{rpm}$ and continued with slow stirring for 5 minutes at a speed of 60 rpm. After the coagulation process is complete, the solution is allowed to stand with a variation of time 0 minutes, 20 minutes, 40 minutes, 60 minutes.

\section{Total Dissolved Solid (TDS) Test}

Samples that had been coagulated with Moringa seed powder associated with each coagulation time, taken with a volume pipette of $50 \mathrm{ml}$ to $100 \mathrm{ml}$, and put into a filter that has been equipped with a vacuum pump and filter paper. After the filtered sample all the filter paper was rinsed 3 times with $10 \mathrm{ml}$ distilled water each, then continue suctioning for about 3 minutes. After perfect filtering, the entire filter was transferred to a cup that has a fixed weight. The filter in the cup was evaporated to dryness over a water bath. A cup containing dissolved solids that have dried was put into the oven at $180^{\circ} \mathrm{C}$ for about 1 hour. Then the cup was removed from the oven with tongs and chill it in a desiccator. When the cup cooled immediately weigh it with an analytical balance. The heating process in the oven was repeated to obtain a fixed weight. According to gravimetric calculations (SNI: 06-6989.27-2005) to get the TDS estimate as follows:

$$
\operatorname{TDS}(\mathrm{mg} / \mathrm{L})=\frac{\left(\mathrm{W}_{1}-\mathrm{W}_{0}\right) \times 10^{6}}{\text { Volume sample test }}
$$

Note: $\mathrm{W}_{0}=$ weight remains empty cup after heating $180^{\circ} \mathrm{C}, \mathrm{W}_{1}=$ fixed weight of the cup containing TDS after $180^{\circ} \mathrm{C}$ heating

Data analysis

To find out the effect of Moringa seed powder concentration and the time of deposition time on the decrease in TDS, analyzed using ANOVA. If there are significant differences, it will be followed by Duncan's multiple range test [8].

\section{RESULT AND DISCUSSION}

Result

Total Dissolved Solid is dissolved solids contained in water. The data results of TDS measurement from cattle wastewater added to the concentration of Moringa seed powder can be seen in Table 1 and Table 2.

TABLE I

DUNCAN TEST RESULT OF TDS LEVEL OF LIVESTOCK WASTEWATER BY CONCENTRATION OF MORINGA POWDER

\begin{tabular}{ccc}
\hline \hline $\begin{array}{c}\text { Concentration of } \\
\text { Moringa }(\mathrm{mg} / \mathrm{L})\end{array}$ & Mean \pm SD & Sig. 0.05 \\
\hline 0 & $2.620,0 \pm 107,28$ & $\mathrm{a}$ \\
50 & $2.550,8 \pm 97,18$ & $\mathrm{~b}$ \\
100 & $2.510,0 \pm 104,62$ & $\mathrm{c}$ \\
150 & $2.536,4 \pm 100,22$ & $\mathrm{~d}$ \\
\hline
\end{tabular}

Note: Values with different letters to the column show significantly different $(\mathrm{P}<0.05)$

TABLE II

DUNCAN TEST RESULT OF TDS LEVEL OF LIVESTOCK WASTEWATER BY TIME OF SIDEMENTATION

\begin{tabular}{clc}
\hline $\begin{array}{c}\text { Time to Sedimentation } \\
\text { (minute) }\end{array}$ & Mean \pm SD & $\begin{array}{c}\text { Sig. } \\
0.05\end{array}$ \\
\hline 0 & $2572,5 \pm 98,82$ & $\mathrm{a}$ \\
20 & $2.540,8 \pm$ & $\mathrm{b}$ \\
& 111,47 & \\
40 & $2529,1 \pm$ & $\mathrm{b}$ \\
& 116,57 & \\
60 & $2503,3 \pm$ & $\mathrm{c}$ \\
\hline
\end{tabular}

Note: Values with different letters to the column show significantly different $(\mathrm{P}<0.05)$, otherwise values with the same letter indicate no significant difference $(\mathrm{P}>0.05)$.

\section{Discussion}

The results of this study showed a decrease in TDS levels, but still above the standard quality of cattle farm waste according to Minister of Environment regulation number 5 of 2014 [3], namely the maximum quality standard of TDS $2.000 \mathrm{mg} / \mathrm{L}$. This is caused by the large amount of organic and inorganic substances contained in cow livestock waste, so that the TDS value was higher than quality standard. Further processing such as filtration is needed.

\section{Effect of Moringa powder concentration on TDS}

The results of variance proved that the concentration of Moringa seed powder has a very significant effect $(\mathrm{P}<0.01)$ on TDS of cattle farm waste. Duncan test results showed concentrations of $0 \mathrm{mg} / \mathrm{L}$ with $50 \mathrm{mg} / \mathrm{L}$, significantly different $(\mathrm{P}<0.05), 0 \mathrm{mg} / \mathrm{L}$ with $100 \mathrm{mg} / \mathrm{L}$ significantly different $(\mathrm{P}<0.05)$ and $0 \mathrm{mg} / \mathrm{L}$ with 150 significantly different $(\mathrm{P}<0.05)$. Concentrations of 50 $\mathrm{mg} / \mathrm{L}$ with $100 \mathrm{mg} / \mathrm{L}$ were significantly different $(\mathrm{P}<0.05)$ and $100 \mathrm{mg} / \mathrm{L}$ with $150 \mathrm{mg} / \mathrm{L}$ were significantly different $(\mathrm{P}<0.05)$. Moringa seed concentration used in this study was able to reduce the TDS value of cattle farm waste. As the concentration used in the study of Januardi and 
Mukarlina [9], the lowest concentration of Moringa seed powder was $66.7 \mathrm{mg} / \mathrm{L}$ was able to provide good results to reduce TDS levels. Decreased levels of TDS occur because Moringa seed powder has a positively charged protein that will bind the negative charges on liquid waste. This statement is strengthened from the results of research by Mubiyi and Evison [10], stating that the decrease in turbidity in waste is caused by the incorporation of a charge between the positively charged Moringa seed protein and the cause of turbidity with negatively charged water, so that the growing flocks will be deposited [11].

\section{Effect of sedimentation time on TDS}

The results of variance proved that each deposition time also has a very significant effect $(\mathrm{P}<0.01)$ on the reduction in TDS of cattle farm waste. Duncan test results on the duration of deposition showed that the duration of deposition of the 0 minute to the 20 minute was significantly different $(\mathrm{p}<0.05)$, the 0 minute to the 40 minute were significantly different $(\mathrm{p}<0.05)$ and the 20 minute to 0 minute with the 60 minute was significantly different $(\mathrm{p}<0.05)$. The duration of the deposition of the 20 minute to the 40 minute was not significantly different ( $>0.05$ ) and the 40th minute to the 60th minute was significantly different. This was confirmed by the study of [12-13] deposition time is the time required to precipitate flocks that have formed in the coagulation process, the cationic protein in the moringa seeds will experience van der Waals force. The van der Waals force is a relatively weak force that works between molecules. To decide the force requires energy around 0.4-40 Id/mol [12-14].

The energy needed to break the van der Waals force is very low or easy to break, if left for a long time the bonds that have formed can be broken down again and TDS levels will increase [15-16]. In this study, for a long time, the deposition of 60 minutes was still effective.

\section{CONCLUSION}

Moringa seed powder at concentration of $50 \mathrm{mg} / \mathrm{L}, 100$ $\mathrm{mg} / \mathrm{L}, 150 \mathrm{mg} / \mathrm{L}$ and the duration of deposition of 20 minutes, 40 minutes, 60 minutes can decreased TDS levels. Moringa seed powder concentration of $150 \mathrm{mg} / \mathrm{L}$ and 60 minutes of deposition time had an optimal effect on TDS levels.

\section{ACKNOWLEDGMENT}

The researcher thanks so much for the farmer group Walung Mekar, Gianyar, and to all those who have helped in the completion of this journal article.

\section{REFERENCES}

[1] Soerjani. 2007. Lingkungan: Semberdaya Alam dan Kependudukan dalam Pembangunan. Jakarta: Indonesia University Press.

[2] Amani F, Prawiroredjo. 2016. Alat Ukur Kualitas Air Minum Dengan Parameter $\mathrm{pH}$, Suhu, Tingkat Kekeruhan, dan Jumlah Padatan Terlarut. JETri. 14(1): 49-62.

[3] Peraturan Menteri Lingkungan Hidup Nomor 5 Tahun 2014. Baku Mutu Air Limbah. Nomor: 1815, 2014.

[4] Goyal BR, Agrawal BB, Goyal RK, Mehta AA. 2007. Phytopharmacology of Moringa oleifera. An overview. Natural Product Radiance. 6(4): 347-353.

[5] Pritchard MT, Craven T, Mkandawire AS, Edmoson JG, O’Neill. 2010. A Study of the Effectiveness of Moringa oleifera in Drinking Water Purification. $J$. Physics and Chemistry of the Earth. 35(13): 791797.

[6] Irmayana, Hadisantoso EP, Soeharti I. 2017, Pemanfaatan Biji Kelor (Moringa oleifera) Sebagai Koagulan Alternatif Dalam Proses Penjernihan Limbah Cair Industri Kulit. Jurnal Istek. 10(2): 4861.

[7] Wibawarto DK, Syafrudin, Nugraha WD. 2017. Study Decrease of Turbidity, TSS, COD Using Moringa Seeds (Moringa Oleifera) as Nano Biocoagulant in Domestic Waste Water Treatment (Grey Water). Jurnal Teknik Lingkungan. 6(1): 2-3.

[8] Sampurna IP, Nindhia TS. 2008. Analisis Data dengan SPSS dalam Rancangan Percobaan. Cetakan I. Denpasar: Udayana University Press.

[9] Januardi R, Setyawati TR, Mukarlina. 2014. Pengolahan Limbah Cair Tahu Menggunakan Kombinasi Serbuk Kelor (Moringa oleifera) dan Asam Jawa (Tamarindus indica). Jurnal Protobiont. 3(1): 41-45.

[10] Mubiyi SA, Evison LM. 1995. Optimizing Physical Parameter Affecting Coagulation of Turbin Water with Moringa oleifera Seeds, Water Res. 29(12): 2689-2695.

[11] Andre, Irawan WW, Endro S. 2015. The Use of Tamarindus indica Seed Powder as Biocoagulant to Reduce the Level of Phosphate and COD in Laundry Wastewater. Jurnal Teknik Lingkungan, 4(4): 1-5.

[12]Umar MR, Liong S. 2014. Efektifitas Serbuk Biji Kelor (Moringa oleifera) Dalam Menurunkan Kadar Kadmium (Cd) pada air. Jurnal Alam dan Lingkungan. 2(3): 37-42.

[13] Cech TV. 2005. Principles of Water Resources, History, Development, Management, and Policy. USA. John Wiley \& Sons.

[14]Akbar IS, A Wahid, M Dia. 2015. Effectiveness Seeds of Moringa (Moringa oleifera Lamk) as 
Coagulant for Iron (Fe) and Calcium (Ca). J. Akademika Kim. 4(2): 64-70.

[15] Amagloh F.K., and A. Benang. 2009. Effectiveness of Moringa Oleifera Seed as Coagulant for Water Purification. Full Length Research Paper. African Journal of Agricultural Research vol. 4(1): 119-123.
[16] Hak A, Kurniasih Y, Hatimah H. 2018. Efektivitas Penggunaan Biji Kelor (Moringa oleifera) Sebagai Koagulan Untuk Menurunkan Kadar TDS dan TSS Dalam Limbah Laundry. J. Kepen. Kim. 6(2): 100113. 